\title{
Preliminary investigation of palaeoclimate signals recorded in the ice core from Dome Fuji station, east Dronning Maud Land, Antarctica
}

\author{
Dome-F Ice Core Research Group* \\ National Institute of Polar Research, Kaga 1-9-10, Itabashi-ku, Tokyo 17.3-8515, Japan
}

\begin{abstract}
An ice core to $2503.52 \mathrm{~m}$ depth was drilled during 1995 and 1996 at $77^{\circ} 19^{\prime} 01^{\prime \prime} \mathrm{S}, 39^{\circ} 42^{\prime} 12^{\prime \prime} \mathrm{E}$ (3810 m a.s. l.), at the summit of Dome Fuji, East Antarctica. Climatic and environmental conditions were observed at the coring site throughout the 2 years of wintering operation. Meteorological and glaciological observations made clear the present surface processes of mass balance. The chemistry of the surface snow layers was observed for investigation of the atmospheric environment reflected in snow deposits.

Core analyses have been carried out in Japan. Permeability and density measurements show that air bubbles are completely closed off by densification processes at about $98 \mathrm{~m}$ depth. The vertical profile of $\delta^{18} \mathrm{O}$ suggests that the core covers two warm stages and one cold stage from the surface down to $1800 \mathrm{~m}$ depth. The transition from the cold to the warm period affects the vertical distribution of ice-crystal size. The chemical constituents in the ice core show large differences between warm and cold periods. A depth age relationship is presented and a study made of palaeoclimatic and core signals.
\end{abstract}

\section{INTRODUCTION}

Snow containing gaseous and particulate aerosols from various sources is deposited on the ice-sheet surface to form layers within the ice sheet. As a consequence, cores drilled through the ice sheet contain an archive of palaeoclimatic and palaeoenvironmental information. This information is detected as both physical and chemical signals. Since the high inland plateau of the Antarctic ice sheet is isolated by distance from local aerosol sources, chemical signals detected in the ice cores are considered to be indicative of the global environment. On the other hand, the physical signals are affected by local environment, including temperature and snow-accumulation rate.

Dome Fuji station ( $77^{\circ} 19^{\prime} 01^{\prime \prime} \mathrm{S}, 39^{\circ} 42^{\prime} 12^{\prime \prime}$ E; $3810 \mathrm{~m}$ a.s.I.) is located about $1000 \mathrm{~km}$ from the coast at the highest point on the high plateau of east Dronning Maud Land, East Antarctica. In 1993, a shallow ice core of $112.59 \mathrm{~m}$ depth was drilled at the station using a dry-hole electromechanical drill. This pilot hole was cased to $80 \mathrm{~m}$ depth. In 1995 and 1996, two overwintering parties then drilled to $2503.52 \mathrm{~m}$ depth using an electromechanical drilling system in a liquid-filled hole. An ice core was collected throughout this depth. Ice-core analyses were carried out, and the preliminary results are presented here together with results of related glaciological and meteorological research.

- Shuhji Aoki, Nobuhiko Azuma, Yoshiyuki Fujii, Shuji Fujita, Teruo Furukawa, Takeo Hondoh, Kokichi Kamiyama, Hideaki Motoyama, Masayoshi Nakawo, Takakiyo Nakazawa, Hideki Narita, Kazuhide Satow, Hitoshi Shoji and Okitsugu Watanabe (principal investigator).
METEOROLOGICAL AND GLACIOLOGICAL MEASUREMENTS AT DOME FUJI STATION

On 11 February 1995, the 36th Japanese Antarctic Research Expedition (JARE-36) commenced overwintering meteorological and glaciological observations at Dome Fuji

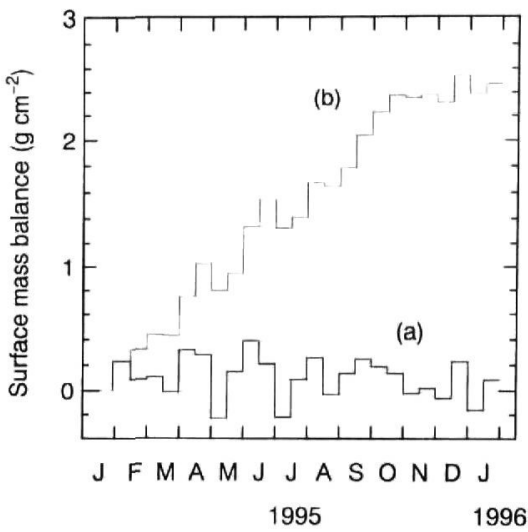

Fig. 1 . Observations of surface mass balance (utilising a farm of 36 snow stakes) at Dome Fuji station from 2.5 January 1995 to 31 January 1996. The thick histogram (a) showes average surface mass balance for each 15-16 day period, and the thin histogram (b) shows cumulative surface mass balance, obtained by integration of histogram (a). 


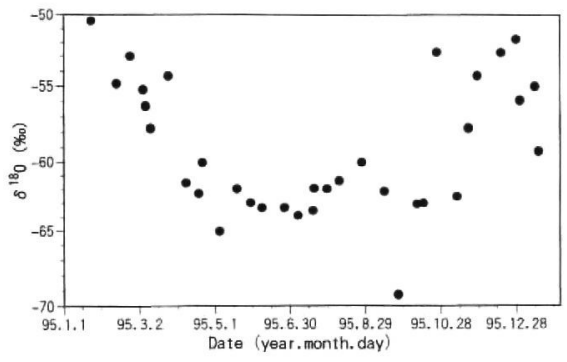

Fig. 2. Seasonal distribution of $\delta^{18} \mathrm{O}$ at Dome Fuji station in 1995 .

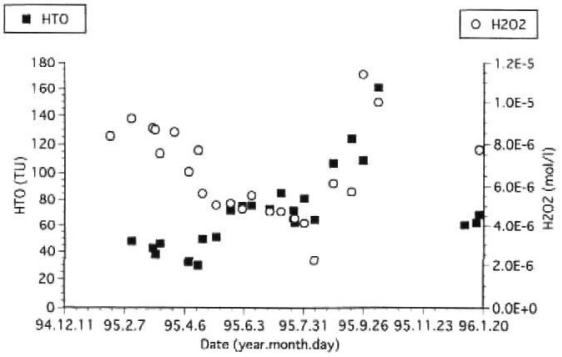

Fig. 3. Seasonal distribution of $\mathrm{H}_{2} \mathrm{O}_{2}$ and $\mathrm{HTO}^{\mathrm{O}}$ at Dome Fuji station in 1995.

station. Data on atmospheric pressure, air temperature, wind direction, wind speed and global solar radiation were automatically recorded Japan Meteorological Agency, 1997; Yoshimi and others, 1997). From March 1995 to February 1996, an annual mean air temperature of $-53.9 \mathrm{C}$ at $1.5 \mathrm{~m}$ height was recorded. The lowest temperature for this period, $-79.7 \mathrm{C}$, occurred on 14 May 1996. Annual mean atmospheric pressure was $598.2 \mathrm{hPa}$, and annual mean wind speed at $10 \mathrm{~m}$ height was $5.8 \mathrm{~m} \mathrm{~s}$. The wind direction sometimes rotated counter-clockwise, and no prevailing wind direction was observed. The most frequent wind direction was northeasterly (in a 16-direction system), but this accounts for only $15 \%$ of the total. Annual mean cloud cover was about $40 \%$. Ice prisms (diamond dust) were observed nearly every day.

Glaciological observations of surface mass balance (utilising a farm of 36 snow stakes, sublimation at the snow surface, and snow temperatures from the surface $1010 \mathrm{~m}$ depth were carried out (Kameda and others, 1997). The average surface mass balance at Dome Fuji station is shown in Figure 1. The thick histogram (a) shows average surface mass balance for each 15-16 day period, and the thin histogram (b) shows cumulative surface mass balance, obtained by integration of histogram (a). It was found for the measurement period 25 January 1995 to 31 January 1996 that the annual surface mass balance was $2.5 \pm 1.0 \mathrm{~g} \mathrm{~cm}^{-2} \mathrm{a}$ ! More than $95 \%$ of the surface mass balance $\left(2.4 \mathrm{~g} \mathrm{~cm}^{2}\right)$ was accounted for by the period February-mid-October. The sur- face mass balance for the rest of the year was reduced $0.1 \mathrm{~g} \mathrm{~cm}^{2}$ for the period mid-October January due to strong sublimation during the austral summer months. In total during 1995, the sublimation process subtracted $\sim 6 \%$ $0.16 \mathrm{~g} \mathrm{~cm}^{2} \mathrm{a}^{1}$ from the surface mass balance. Measurements of vertical distribution of snow temperature through 1995 revealed an average $10 \mathrm{~m}$ temperature of $-57.3 \mathrm{C}$.

\section{DISTRIBUTION OF OXYGEN ISOTOPE RATIO AND CONCENTRATION OF CHEMICAL CON- STITUENTS IN SURFACE SNOW}

The seasonal distribution of $\delta^{18} \mathrm{O}$ in the surface snow at Dome Fuji is in the range $-50 \%$ to $65 \%$, increasing in summer and decreasing in winter, as shown in Figure 2. Some of the chemical constituents tritium HTO, K, Ca, $\mathrm{F}, \mathrm{Cl}$ and $\mathrm{SO}_{4}$ ) increased in concentration in early summer and decreased in early winter. Others $\mathrm{H}_{2} \mathrm{O}_{2}$, methane sulphonic acid (MSA), $\mathrm{CH}_{3} \mathrm{COO}, \mathrm{HCOO}, \mathrm{NO}_{3}, \mathrm{Mg}$ and $\mathrm{NH}_{4}$ ) also increased in concentration in early summer and late autumn, but decreased in late summer and winter. Plots of $\mathrm{HTO}$ and $\mathrm{H}_{2} \mathrm{O}_{2}$ concentration are shown in Figure 3. Atmospheric circulation and chemical reactions in the atmosphere affect the seasonal fluctuations of chemical concentrations in snow. For example, it is considered that HTO is transported only in the stratosphere, while $\mathrm{H}_{2} \mathrm{O}_{2}$ is transported in the stratosphere and increasingly in the troposphere during late autumn. Detailed information is needed on the seasonal fluctuations reflected by the transportation

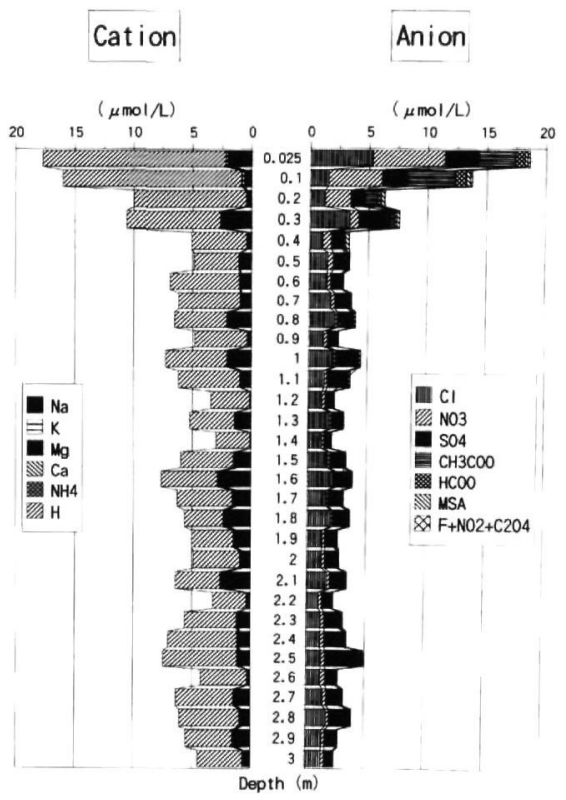

Fig. 4. Concentrations of major chemical impurities in the surface snow layers at Dome Fiji station. 


\section{Dome-F Ice Core}

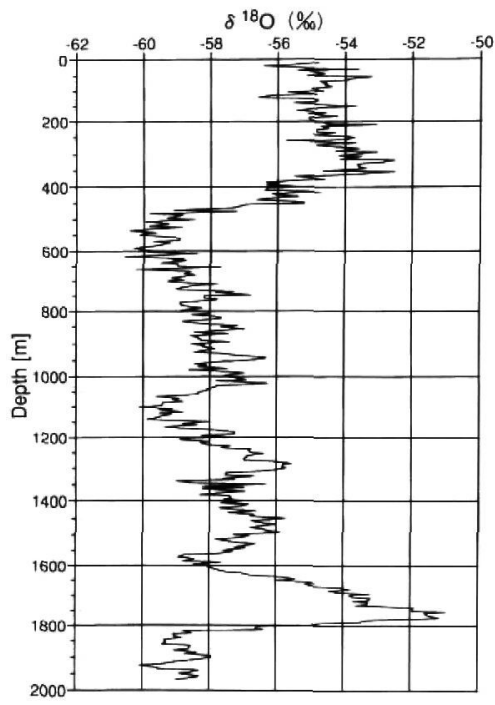

Fig. 5. Preliminary profile of $\delta^{1 B} O$ of Dome Fuji deep core. Data plotted at $5 \mathrm{~m}$ intervals to a depth of $2000 \mathrm{~m}$.

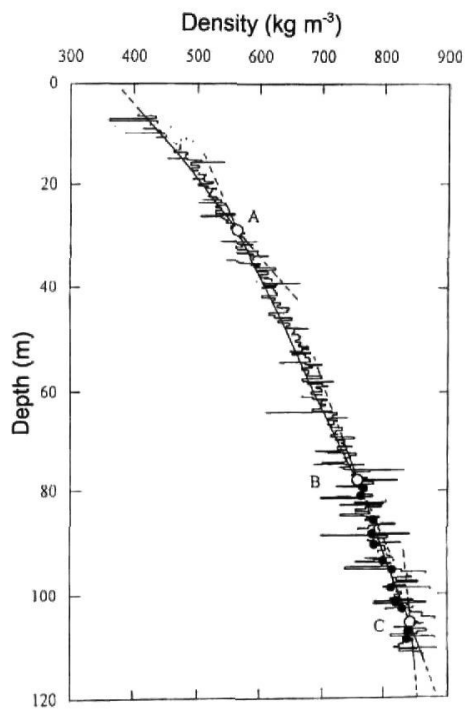

and chemical reaction processes in the atmosphere for comparison with data from the Arctic (Beer and others, 1991).

Stratigraphic observations, density measurements and snow sampling for chemical analyses were conducted in 2 $3 \mathrm{~m}$ deep snow pits four times during 1995. A distinct structure consisting of stratified layers composed of alternate hard-packed and loose snow is observed in the deposited snow at Dome Fuji Station. The hard layers are composed of a mixture of comparted snow and hard-type depth hoar. The loose layers are skeleton-type depth hoar. Variations in the concent rations of major chemical constituents in the surface layers are shown in Figure 4. These may suggest the occurrence of migration processes in the snowpack.

\section{LABORATORY ANALYSES OF ICE CORES}

The whole of the top $112.59 \mathrm{~m}$ of the Dome Fuji ice core obtained in 1993 by dry-hole electromechanical drilling is available for laboratory analysis in Japan. Ice core to a depth of 2503.52 $\mathrm{m}$ was obtained in 1995 and 1996 using an electromechanical drill in a liquid-filled borcholc. This ice core (i.c. the material deeper than $112.59 \mathrm{~m}$ ) was divided in the field, vertically into $40 \%$ and $60 \%$ (cross-sectional area) sections. The sections comprising $40 \%$ of the core were transported to Japan in 1995 and 1996 for laboratory analysis. The other sections remain at Dome Fuji station.

\section{Oxygen isotope ratio}

Stable-isotope ratios of oxygen and hydrogen were deter-

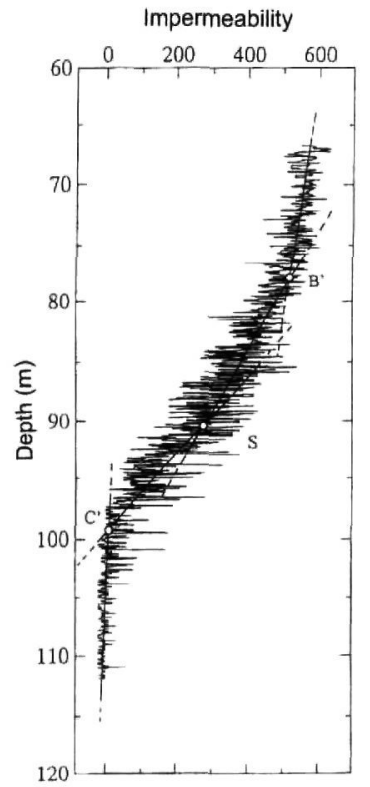

Fig. 6. Vertical profiles of impermeability and butk density at Dome Fiji station. Bulk density profile is divided at transition depths, A, B and C. The depths and bulk densities are $A\left(28 \mathrm{~m}, 560 \mathrm{~kg} \mathrm{~m}^{3}\right), B\left(77 \mathrm{~m}, 740 \mathrm{~kg} \mathrm{~m}^{3}\right)$ and $C\left(106 \mathrm{~m}^{3}, 840 \mathrm{~kg} \mathrm{~m}^{3}\right)$. $B^{\prime}$ and $C^{\prime \prime}$ in the impermeability profile correspond roughly to $B$ and $C$ Bubble close-off begins at about $90 \mathrm{~m}$ depth ( $S$ ) and closeoff is complete at depth $C^{\prime \prime}(98 \mathrm{~m})$. 


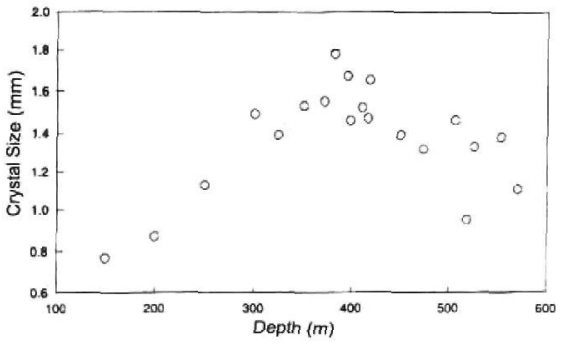

Fig. 7. Vertical profite of crustal size at Dome Fuji station.

mined from $50 \mathrm{~cm}$ long samples (so-called bag samples). For some selected core sections, more detailed sampling was carried out. Samples weighing $25-35 \mathrm{~g}$ were cut with a band-saw and washed to reduce contamination from drilling fluid ( $n$-butyl acetate).

The standard $\mathrm{CO}_{2}$ equilibrium method was employed for $\delta^{18} \mathrm{O}$ analysis, normally using $5 \mathrm{ml}$ water samples and two sets of secondary working standards for each batch of samples. The routine measurement accuracy is $\pm 0.1 \%$

A preliminary plot of $\delta^{18} \mathrm{O}$ as a function of depth to a depth of $2000 \mathrm{~m}$ is shown in Figure 5. The transition from ice deposited during the Wisconsin period to that deposited during the Holocene occurs at $350-550 \mathrm{~m}$ depth. The Wisconsin/Eemian transition is located at $1600-1750 \mathrm{~m}$ depth.

\section{Density, permeability and crystal size}

The depth protiles of density and air permeability for the Dome Fuji core are shown in Figure 6. Density increases gradually with depth. and air bubbles are completely closed at a depth of $98 \mathrm{~m}$ (Watanabe and others, 1997). Crystal size increases with depth down to $350400 \mathrm{~m}$. and then decreases from 400 to $6000 \mathrm{~m}$, as shown in Figure 7. The depth at which the change from increasing to decreasing crystal size occurs coincides approximately with the transition from Holocene to Wisconsin ice.

\section{Chemical constituents}

The chemical constituents of the core samples were measured by ion chromatography. Ions measured include cations $\left(\mathrm{NH}_{4}, \mathrm{Na}, \mathrm{K}, \mathrm{Mg}\right.$ and $\left.\mathrm{Ca}\right)$ and anions with weak acidic components (F, Cl, $\mathrm{SO}_{4}, \mathrm{NO}_{3}, \mathrm{NO}_{3}, \mathrm{HCOO}, \mathrm{CH}_{3} \mathrm{COO}$, $\mathrm{C}_{2} \mathrm{O}_{2}, \mathrm{MSA}$ ). The proliles of the major components of sea salts $\mathrm{Na}, \mathrm{Cl}$ ) and ions of secondary origin (MSA are shown in Figure 8. 'There are large environmental changes evident between the glacial and interglacial periods.

\section{ICE-CORE CHRONOLOGY}

The net snow-accumulation rate at Dome Fuji station was estimated by three different methods: the snow stake method, fission-product tracer analysis and electrical conductivity measurement (ECM). Profiles of HTO and gross $\beta$ activity are shown in Figure 9, Volcanic eruption events occurring at known times are indicated by increased ECM values as shown in Figure 10. Each of these methods suggests
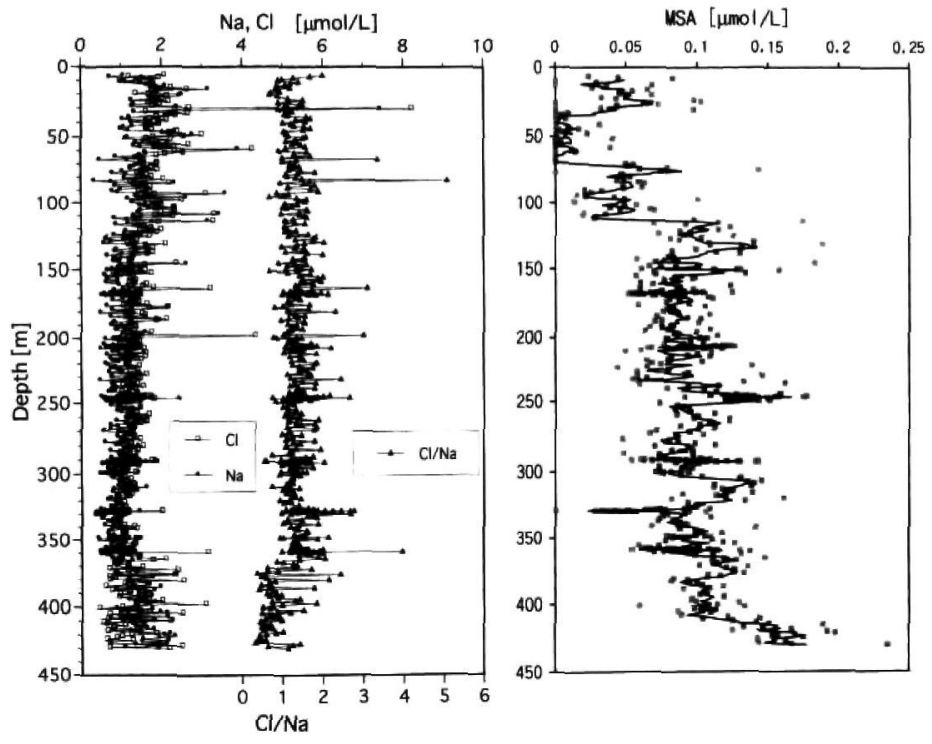

Fig. 8. Verical profiles of major components of sea salts ( $\mathrm{Na}, \mathrm{Cl}$ ) and ions of secondary origin ( $M S \mathrm{~S}$ ). 


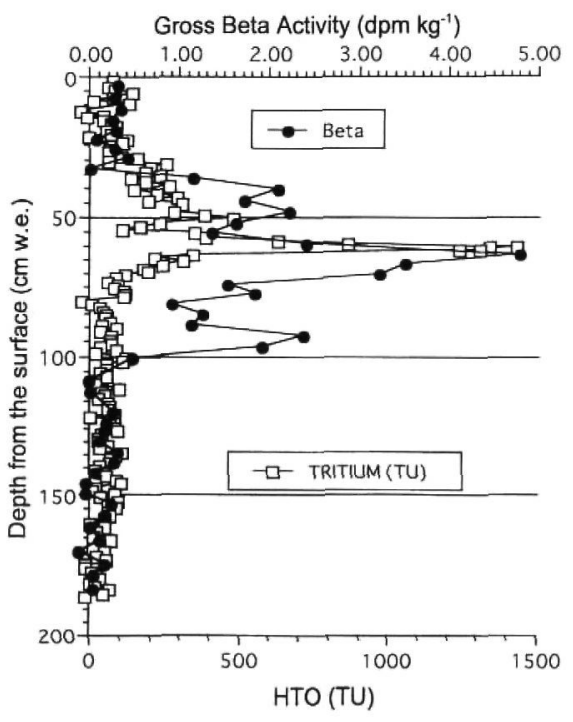

Fig. 9. Vertical profiles of HTO and gross $\beta$ activity at Dome Camp near Dome Fuji station.
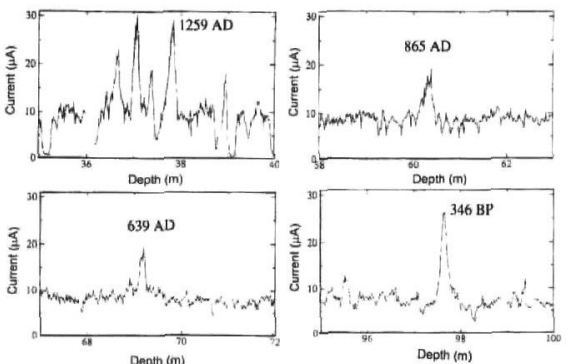

Fig. 10. ECM data used for dating by detecting volcanic eruptions which occurred at known times.

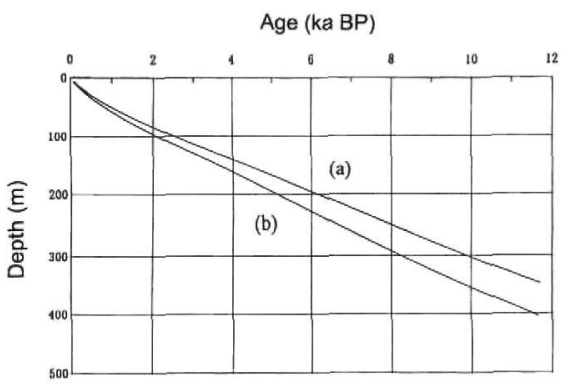

Fig. 11. Depth age curves calculated with accumulation rate values of (a) 25 and (b) $30 \mathrm{~mm}$ w.e. $a^{-t}$. a similar accumulation rate of $\sim 30 \mathrm{~mm}$ w.e. ${ }^{1}$ for the Holocene period. This estimate is compatible with the Holocene/Wisconsin transition depth provided by the $\delta^{18} \mathrm{O}$ data.

By assuming a decreased net snow accumulation rate during the glacial periods, the depth age relationship shown in Figure 11 is obtained. This relationship indicates that the $2503.52 \mathrm{~m}$ deep Dome Fuji ice core covers the last $330 \mathrm{ka}$. This is supported by comparison of the profiles of $\delta^{18} \mathrm{O}$ with those from the (so far, more accurately dated) Vostok ice core.

\section{GONCLUSIONS}

The results obtained so far highlight several characteristics as follows.

There is substantial depth-hoar development during the snow metamorphism process in the surface snow layers. This may modify chemical signals which were originally indicative of atmospheric conditions.

The continuous $\delta^{18} \mathrm{O}$ profile for the core suggests that the depth of the Holocene/Wisconsin transition is $\sim 380 \mathrm{~m}$, indicating an annual mean snow accumulation rate of approximately $3.0 \mathrm{~g} \mathrm{~cm}^{-2} \mathrm{a}^{-1}$ for the Holocene. This coincides with values obtained from fission-product tracers and the snow stake method. A depth-age relationship was obtained from the ice-sheet surface to $2500 \mathrm{~m}$ depth by estimating a decreased rate for precipitation during the glacial periods.

Measurements have been carried out for snow chemistry and $\delta^{18} \mathrm{O}$, as well as volcanic event analyses with ECM. Profiles of snow chemistry and $\delta^{18} \mathrm{O}$ suggest the occurrence of large environmental changes between glacial and interglacial periods. $\delta^{18} \mathrm{O}$ and chemical concentration and ice-crystal size show large fluctuations at the depths of the Holocene/Wisconsin and Wisconsin/ Eemian transitions.

\section{REFERENCES}

Becr, J. and T5 others, 1991. Seasonal variations in the concentrations of ${ }^{10} \mathrm{Be}$. $\mathrm{Cl}, \mathrm{NO}_{3}, \mathrm{SO}_{4}{ }^{2}, \mathrm{H}_{2} \mathrm{O}_{2},{ }^{2010} \mathrm{~Pb},{ }^{3} \mathrm{H}$ mineral dust and ${ }^{113} \mathrm{O}$ in Greenland stow. Atmos. Enviran., Ser. A. 25 (5-6), 899904.

Japan Meteorological Agency. 1997. Meteorological data al Syazua Station and Dome Fuji Station in 199.5. Tokyo, Japan Meteorological Agency: Antarctic Meteorological Data 36.)

Kameda, T., N. Azuma, T. Furukawa, Y. Ageta and S. Takahashi. 1997. Surface mass balance, sublimation and snow temperatures at Dome Fiji Station. Antarctica, in 1995. Proc. NIPR Symp. Polar Meteorol. Cilarial. II, 24.34.

Watanabe, O. and 12 others. 1997. Preliminary discussion of physical properties of the Dome Fuji shallow ice core in 1993, Antarctica. Proc, NTPR Symp. Polar Aeteorol. Glaciol. II, I-8.

Yoshimi, H., N. Azuma, T. Yamanouchi, S. Takahashi and O. Watanabe. 1997. Year-round surface synoptic observations at Dome Fiji Station. East Antarctica conducted by the first overwintering party. [Abstract.] Proc. NTPR Symp. Polar Meicaral Giaciol. 11, 258. 